\title{
Article \\ Induced Effect of Gold Nanoparticles (AuNPs) and Halide Ions on Pyridoxine Molecule Stability
}

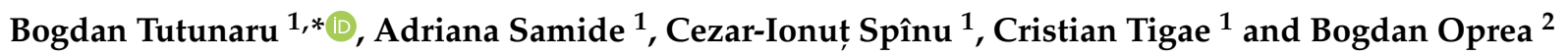 \\ 1 Department of Chemistry, Faculty of Sciences, University of Craiova, CUI: 4553380, Calea București 107i, \\ 200478 Craiova, Dolj, Romania; samide_adriana@yahoo.com (A.S.); spinu_cezar@yahoo.com (C.-I.S.); \\ ctigae@yahoo.com (C.T.) \\ 2 Faculty of Medicine, University of Medicine and Pharmacy, Petru Rareș 2, 200349 Craiova, Dolj, Romania; \\ oprea.bogdan@yahoo.com \\ * Correspondence: tutunaruchim@yahoo.com; Tel.: +40-251-597048
}

check for updates

Citation: Tutunaru, B.; Samide, A.; Spînu, C.-I.; Tigae, C.; Oprea, B. Induced Effect of Gold Nanoparticles (AuNPs) and Halide Ions on Pyridoxine Molecule Stability. Appl. Sci. 2021, 11, 9470. https://doi.org/ 10.3390/app11209470

Academic Editor: Raed Abu-Reziq

Received: 10 September 2021

Accepted: 8 October 2021

Published: 12 October 2021

Publisher's Note: MDPI stays neutral with regard to jurisdictional claims in published maps and institutional affiliations.

Copyright: (c) 2021 by the authors. Licensee MDPI, Basel, Switzerland. This article is an open access article distributed under the terms and conditions of the Creative Commons Attribution (CC BY) license (https:// creativecommons.org/licenses/by/ $4.0 /)$.

\begin{abstract}
The electrochemical behavior of pyridoxine was studied in $0.1 \mathrm{~mol} \times \mathrm{L}^{-1} \mathrm{NaX}(\mathrm{X}=\mathrm{F}, \mathrm{Cl}, \mathrm{Br})$ support electrolyte on a gold electrode using cyclic voltammetry and UV-Vis spectrophotometry. The influence of gold nanoparticles (AuNPs) on the electrochemical behavior of pyridoxine was studied. The experimental results obtained by both cyclic voltammetry and UV-Vis spectrophotometry indicate strong interactions in the $\mathrm{B}_{6}$ and $\mathrm{NaBr} / \mathrm{NaCl} \_\mathrm{AuNP}$ systems, while in the $\mathrm{NaF}_{-} \mathrm{B}_{6} \_\mathrm{AuNP}$ ternary system the results indicate a mechanism of direct electrochemical degradation of vitamin $\mathrm{B}_{6}$. The experimental results obtained for the electrochemical degradation of pyridoxine, in the presence of chloride and bromide ions, indicate strong interactions in the $\mathrm{NaCl}_{-} \mathrm{B}_{6} \_\mathrm{AuNP}$ and $\mathrm{NaBr} \_\mathrm{B}_{6} \_\mathrm{AuNP}$ systems associated with the spectrophotometric identification of the electrogenerated intermediates, while in the presence of fluoride ions no such products are identified. The development of the mechanism of electrochemical degradation of the pyridoxine molecule predicts both the formation of the corresponding electrogenerated intermediates and the steps of electro-incineration in a direct mechanism.
\end{abstract}

Keywords: pyridoxine; gold nanoparticles; electrochemical behavior; spectrophotometry

\section{Introduction}

Vitamin $\mathrm{B}_{6}$ (other names: pyridoxine, pyridoxol, pyridoxine hydrochloride) belongs to the group of soluble $B$ vitamins that are involved in metabolic processes and plays an important role in human health and especially in DNA repair, for which it is an essential cofactor [1]. It is involved in the pathways of methyl-group metabolism as a cofactor for different important enzymes, thus being a protective nutrient for pancreatic cancer by preventing the alteration of the DNA methylation mechanism [2]. Precisely because of its importance in the body, this vitamin has been introduced in food supplements to combat its deficiency as a food additive with an antioxidant role and even in drugs, alone or in various multivitamin complexes. $\mathrm{B}_{6}$ vitamers with common 2-methyl-3-hydroxypyridine structures (pyridoxine- $\mathrm{P}$, pyridoxal-PO, pyridoxamine- $\mathrm{PN}$ and the corresponding 5'-phosphorylated derivatives; pyridoxine 5'-phosphate-P5P, pyridoxal 5'-phosphatePO5P and pyridoxamine 5'-phosphate-PN5P) are biologically active compounds, known since the early 1900s and comprising six interconvertible members under the action of specific enzymes [1]. Pyridoxal-5' -phosphate is the form of $\mathrm{B}_{6}$ vitamin that is biologically active, being produced in human organisms from the vitamers. It is involved in the regulation mechanisms of the glucose, lipid and amino-acid metabolism as a co-enzyme for about 160 different enzymatic reactions. The survival rate of non-small cell lung cancer patients was correlated with high levels of pyridoxal kinase, while the vitamin $\mathrm{B}_{6}$ intake was inverse associated with colorectal cancer risk [3]. The antagonistic properties of $\mathrm{B}_{6}$ vitamers have been discovered over time, so they are powerful antioxidants (inactivate 
reactive oxygen species) but can also act as endogenous photosensitizers that lead to the formation of reactive oxygen species [1].

Along with vitamin $B_{1}$ and $B_{12}$, pyridoxine is involved in peripheral nerve repair processes through mechanisms that are yet to be fully understood. The evidence for this role was provided by numerous animal studies over time, and now these elements are referred to as "neurotropic" vitamins. Pyridoxine plays a very important role in the synthesis of neurotransmitters and in inhibition of neurotoxic glutamate [4].

Vitamin $B_{6}$ is obtained industrially through fermentation processes, so it was necessary to develop more and more efficient methods to ensure maximum production efficiency and, on the other hand, a simple and accurate method of determining the concentration of this vitamin. Application of the liquid chromatography (LC) method using different detection techniques for determination of vitamin $\mathrm{B}_{6}$ in pharmaceutical formulations, plant foods, human plasma and serum demonstrated a high degree of sensitivity, precision and linearity [5-10]. Determination of vitamin $\mathrm{B}_{6}$ in tablets by LC with electrochemical detection using a carbon fiber electrode showed a detection limit of $2.5 \mathrm{ng}$ for $\mathrm{P}$ and $1.0 \mathrm{ng}$ for PO and PN [5]. LC coupled to mass spectrometry (MS) provided a good linearity between 5.0 and $400.0 \mathrm{ng} \times \mathrm{mL}^{-1}$ [6]. High-performance LC (HPLC) with coulometric electrochemical and ultraviolet detection using C18 column type indicated detection limits of 2.7 [7] and $0.18 \mathrm{ng} \times \mathrm{mL}^{-1}$ [8]. Simultaneous determination of vitamin $\mathrm{B}_{6}$ in the presence of co-administrated compounds such as other vitamins or antiepileptics showed a good predictability with reversed-phase HPLC (RP-HPLC) $[9,10]$. Limits of quantification of $0.39 \mu \mathrm{g} \times \mathrm{mL}^{-1}$ and $0.11 \mathrm{ng} \times \mathrm{mL}^{-1}$ were obtained in the presence of levetiracetam and $\mathrm{B}_{1} / \mathrm{B}_{12}$, respectively.

Experimental determination of vitamin $\mathrm{B}_{6}$ can involve some analytical impediments due to its complex structure that can lead to the appearance of intermolecular interferences. Some studies involved vitamin $\mathrm{B}_{6}$ separation and determination in food, dietary supplements and pharmaceutical tablets using various spectrometric techniques [11-16]. UV-Vis spectrophotometry applied in the analysis of samples containing vitamin $\mathrm{B}_{6}$, showed an increase in sensitivity followed by a decrease in detection limits to values of about $60 \mathrm{ng} \times \mathrm{mL}^{-1}$ [11], $5-25 \mu \mathrm{g} \times \mathrm{mL}^{-1}$ [12] and 2-21 $\mu \mathrm{g} \times \mathrm{mL}^{-1}$ [13]. The use of fluorescence spectrophotometry, without or with a CdSe quantum dot sensor, also led to detection limits of 33-450 $\mu \mathrm{g} \times \mathrm{mL}^{-1}[14,15]$. UV-Vis spectrophotometry, fluorescence spectrophotometry and FTIR spectroscopy allowed the individual physicochemical study of pyridoxine as well as its interactions with bovine serum albumin [16].

Although these methods have advantages such as selectivity and sensitivity, they also have certain limitations, such as high costs, elaborate sample preparation processes and long analysis time. Compared to these methods, electrochemical sensors have been introduced and developed as a modern alternative for determining vitamins [17-30]. Electrochemical sensors have a much greater simplicity, miniaturization, reproducibility, low cost and high sensitivity, and among them, vitamin sensors based on carbonaceous materials, namely glassy carbon electrodes [18-21], carbon ceramic electrodes [22], graphite, [23,24], screen printed carbon [25], multiwalled carbon nanotubes [26,27], graphene [28] and borondoped diamond $[29,30]$ have been used. The performance of the electrochemical sensors for detecting water-soluble vitamins $\left(\mathrm{B}_{1}, \mathrm{~B}_{2}, \mathrm{~B}_{6}, \mathrm{~B}_{9}, \mathrm{~B}_{12}, \mathrm{C}\right)$ and fat-soluble vitamins $(\mathrm{A}$, $\mathrm{D}, \mathrm{E}, \mathrm{K})$ varies from the nano to micro scale and takes into account the electrochemical processes of vitamins on the electrode surface [17-34]. Sensitive hybrid heterostructures such as $\mathrm{SnO}_{2}$ nanoparticles supported mesoporous $\mathrm{TiO}_{2}$ over glassy carbon electrodes [31], $\mathrm{Au}-\mathrm{CuO}$ core-shell/multiwalled carbon nanotubes [32], calix-8-arene/phosphotungstic acid/di isooctyl phthalate [33] and $\beta$-cyclodextrin/carboxylated poly(vinyl chloride) [34] are reported for pyridoxine determination.

Nanomaterials incorporating electrochemical sensors for vitamin $\mathrm{B}_{6}$ determination are an excellent class of materials due to their unique multifunctionality [35]. Synthesis, characterization and application of gold and silver nanoparticles are revolutionizing all the fields to which they are applied [36-39]. Probably the most important applications are the 
detection, diagnosis and therapy of cancer with gold nanoparticles [40,41]. Despite their valuable properties and bio-applications, gold and silver nanoparticles also have negative aspects, such as toxicity [42-44]. The synthesis and use of gold and silver nanoparticles and even gold-silver bimetallic nanoparticles in the removal of pollutants from polluted waters have been reported [44-49].

Simultaneously with pyridoxine, the halide ions can be ingested from food or by administering sodium halide-containing drugs. In particular cases, the gold nanoparticles can be an option for antiviral treatment, inducing immunostimulatory activity. In this context, it is important to study the concerted action of these biologically active compounds. Various interactions between halide ions and vitamin molecules or AuNPs can occur, leading to the inhibition or stimulation of vitamin degradation reaction. Consequently, the present study aimed to highlight the induced effects by gold nanoparticles on the decomposition/transformation reaction of $\mathrm{B}_{6}$ vitamin molecules. Concomitantly, the influence of $B_{6}$ vitamin molecules and halide ions on the on the activity of gold nanoparticles was investigated.

Given all these findings, we conducted studies related to the competition between vitamin $B_{6}$, gold nanoparticles and halide anions by exploiting the sensitivity of their electrochemical properties. We performed electrochemical and spectrophotometric characterization of their binary and ternary systems (NaX/AuNPs; $\mathrm{NaX} / \mathrm{B}_{6} ; \mathrm{NaX} / \mathrm{B}_{6} / \mathrm{AuNPs}$ ) to determine if there is a strong interaction between the species present in the solution.

\section{Materials and Methods}

\subsection{Materials}

Vitamin $\mathrm{B}_{6}$ was purchased (ZENTIVA SA ROMANIA) as $5 \mathrm{~mL}$ vials containing the active substance pyridoxine as pyridoxine hydrochloride at a concentration of $250 \mathrm{mg} / 5 \mathrm{~mL}$ with pure water. Single use vials of $250 \mathrm{mg} / 5 \mathrm{~mL}$ vitamin $\mathrm{B}_{6}$ solution for muscularly or intravenous use only was used as stock solutions. $\mathrm{NaF}, \mathrm{NaCl}$ and $\mathrm{NaBr}$ used as supporting electrolyte were of AR grade and acquired from Fluka. Gold nanoparticle (AuNP) suspension was purchased from AquaNano (Aghoras Invent srl, Bucharest) as $480 \mathrm{~mL}$ bottles with a concentration of $110 \mathrm{mg} \times \mathrm{L}^{-1}$.

Four working solutions were used as follows:

(i) $0.1 \mathrm{~mol} \times \mathrm{L}^{-1} \mathrm{NaX}(\mathrm{NaX}$ curves);

(ii) $0.1 \mathrm{~mol} \times \mathrm{L}^{-1} \mathrm{NaX}, 2.9 \times 10^{-4} \mathrm{~mol} \times \mathrm{L}^{-1} \mathrm{~B}_{6}$, (NaX_B $\mathrm{B}_{6}$ curves);

(iii) $0.1 \mathrm{~mol} \times \mathrm{L}^{-1} \mathrm{NaX}, 75 \mathrm{mg} \times \mathrm{L}^{-1}$ AuNPs, $\left(\mathrm{NaX} \_\right.$AuNP curves);

(iv) $0.1 \mathrm{~mol} \times \mathrm{L}^{-1} \mathrm{NaX}, 2.9 \times 10^{-4} \mathrm{~mol} \times \mathrm{L}^{-1} \mathrm{~B}_{6}, 75 \mathrm{mg} \times \mathrm{L}^{-1} \mathrm{AuNPs}$, (NaX_B B $_{6}$ AuNP curves).

All solutions were freshly prepared and used on the same day.

\subsection{Methods}

Cyclic voltammetry and electrolysis at constant current density $\left(50 \mathrm{~mA} \times \mathrm{cm}^{-2}\right)$ were performed using a VoltaLab 40 controlled by a PC using VoltaMaster 4 software.

Cyclic voltammograms were recorded at a scan rate of $100 \mathrm{mV} \times \mathrm{s}^{-1}$, using a traditional one-compartment three electrode electrochemical cell consisting of two gold electrodes (work and counter electrode) and an $\mathrm{Ag} \mid \mathrm{AgCl}, \mathrm{KCl}$ sat reference electrode. The working electrode and the counter electrode were made of glossy gold and had a geometric surface of $1 \times 1 \times 0.1 \mathrm{~cm}$.

All voltammetric experiments were performed in stirred conditions at stirring rate of $300 \mathrm{rpm}$ (with a magnetic bar) in order to prevent any diffusion problems.

Controlled current density electrolysis $\left(50 \mathrm{~mA} \times \mathrm{cm}^{-2}\right)$ was performed in tandem with UV-Vis spectrophotometry. UV-Vis spectra changes for each of the four working solutions were evaluated with a VarianCary spectrophotometer (CaryWin UV software) using quartz cuvettes with $1 \mathrm{~cm}$ optical path.

The experimental conditions and methods are presented in previous articles of the authors [39,48,50-55]. 


\section{Results and Discussion}

Cyclic voltammograms of the four systems (NaX; NaX_B 6 ; NaX_AuNPs and NaX_B ${ }_{6}$ AuNPs) were produced to study the redox behavior of pyridoxine at a glossy gold electrode in dynamic experimental conditions.

\subsection{The Influence of Fluoride Ions on Electrochemical Behavior of Pyridoxine}

Figure 1 presents a comparison of the voltammograms recorded on the gold electrode in the supporting electrolyte of $0.1 \mathrm{~mol} \times \mathrm{L}^{-1} \mathrm{NaF}$, in the absence and in the presence of $75 \mathrm{mg} \times \mathrm{L}^{-1}$ AuNPs and $2.9 \times 10^{-4} \mathrm{~mol} \times \mathrm{L}^{-1}$ pyridoxine (vitamin $\mathrm{B}_{6}$ ).
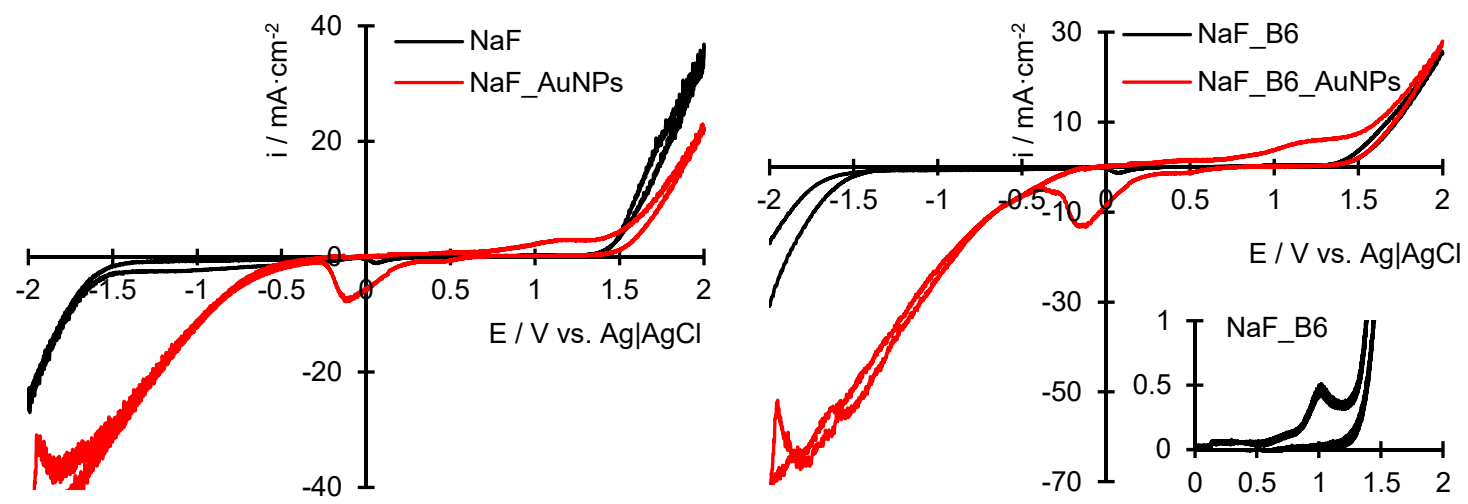

Figure 1. Cyclic voltammetry responses of gold electrode in $0.1 \mathrm{~mol} \times \mathrm{L}^{-1} \mathrm{NaF}$ support electrolyte in the absence and in the presence of $75 \mathrm{mg} \times \mathrm{L}^{-1}$ gold nanoparticles (AuNPs) and $2.9 \times 10^{-4} \mathrm{~mol} \cdot \mathrm{L}^{-1}$ pyridoxine (vitamin $\mathrm{B}_{6}$ ).

As can be seen, the supporting electrolyte leads to a higher peak corresponding to the potential range between 1.5 and $2.0 \mathrm{~V}$. However, the addition of gold nanoparticles in the electrolyte solution leads to the appearance of a new wide peak of the current density recorded between 0.8 and $1.5 \mathrm{~V}$ vs. $\mathrm{Ag} \mid \mathrm{AgCl}$ reference electrode. At high values of the anodic overvoltage, oxides/hydroxides $\left(\mathrm{AuOH}, \mathrm{AuO}, \mathrm{Au}_{2} \mathrm{O}_{3}\right)$ are formed on the surface of the gold electrode [56]. The electrogeneration of oxides on the surface of the gold electrode modifies the catalytic properties of the surface [56], which can lead to various mechanisms of electrochemical degradation of pyridoxine molecules. The onset potential for initiating the growth of the mixed oxide/hydroxide layer is about $1.35 \mathrm{~V}$. The irreversible feature in the gold response is the huge anodic peak that extends in the range of 1.5 to $2.0 \mathrm{~V}$.

In terms of electrochemical properties, the potential range from 1.5 to $2.0 \mathrm{~V}$ is very important because, in addition to oxygen depolarization, there is also the continuous change of the electrode/electrolyte interface. In this range of potential, gold nanoparticles oxidize (NaF_AuNP curve). The properties of gold nanoparticles are highlighted so that the anodic current densities are considerably reduced in their presence, decreasing from 37 (NaF curve) to $22 \mathrm{~mA} \times \mathrm{cm}^{-2}$ (NaF_AuNP curve). According to the cyclic voltammogram $\mathrm{NaF}_{-} \mathrm{B}_{6}$, lower values of anodic current densities are recorded, compared to that of the supporting electrolyte. This is due to the strong adsorption processes of organic vitamin molecules on the surface of the gold electrode. The electrochemical analysis highlights the heterogeneous oxidation processes corresponding to the oxidation of organic molecules by the appearance of an anodic peak, well defined by low intensity at anodic potential of $0.9 \mathrm{~V}$. In the detail of the $\mathrm{NaF}_{-} \mathrm{B}_{6}$ curve, shown in Figure 2, there is a clear increase in current densities starting with potential greater than $0.8 \mathrm{~V}$. This is also the onset potential corresponding to the charge transfer in which the pyridoxine molecules are involved. The simultaneous presence in the electrolyte solution of pyridoxine and nanoparticles (NaF_B ${ }_{6 \_}$AuNP curve) has an antagonistic effect, thus reducing the anodic current densities corresponding to oxygen depolarization ( $\mathrm{NaF}$ curve), but at the same time has higher current densities compared to the NaF_AuNP curve. The characteristics and appearance of cyclic voltammograms also changes during cathodic polarization. The 
cathodic polarization highlights the appearance of a peak of the cathodic current density in the support electrolyte, with low intensity $\left(0.7 \mathrm{~mA} \times \mathrm{cm}^{-2}\right)$, due to the reduction of oxides/hydroxides on the surface of the gold electrode. Characteristic to this peak is that, in the presence of gold nanoparticles, the peak intensity increases to $7.5 \mathrm{~mA} \times \mathrm{cm}^{-2}$, and in the ternary system $\left(\mathrm{NaF}_{-} \mathrm{B}_{6}{ }_{-} \mathrm{AuNPs}\right)$ it has the highest value of $12.6 \mathrm{~mA} \times \mathrm{cm}^{-2}$.
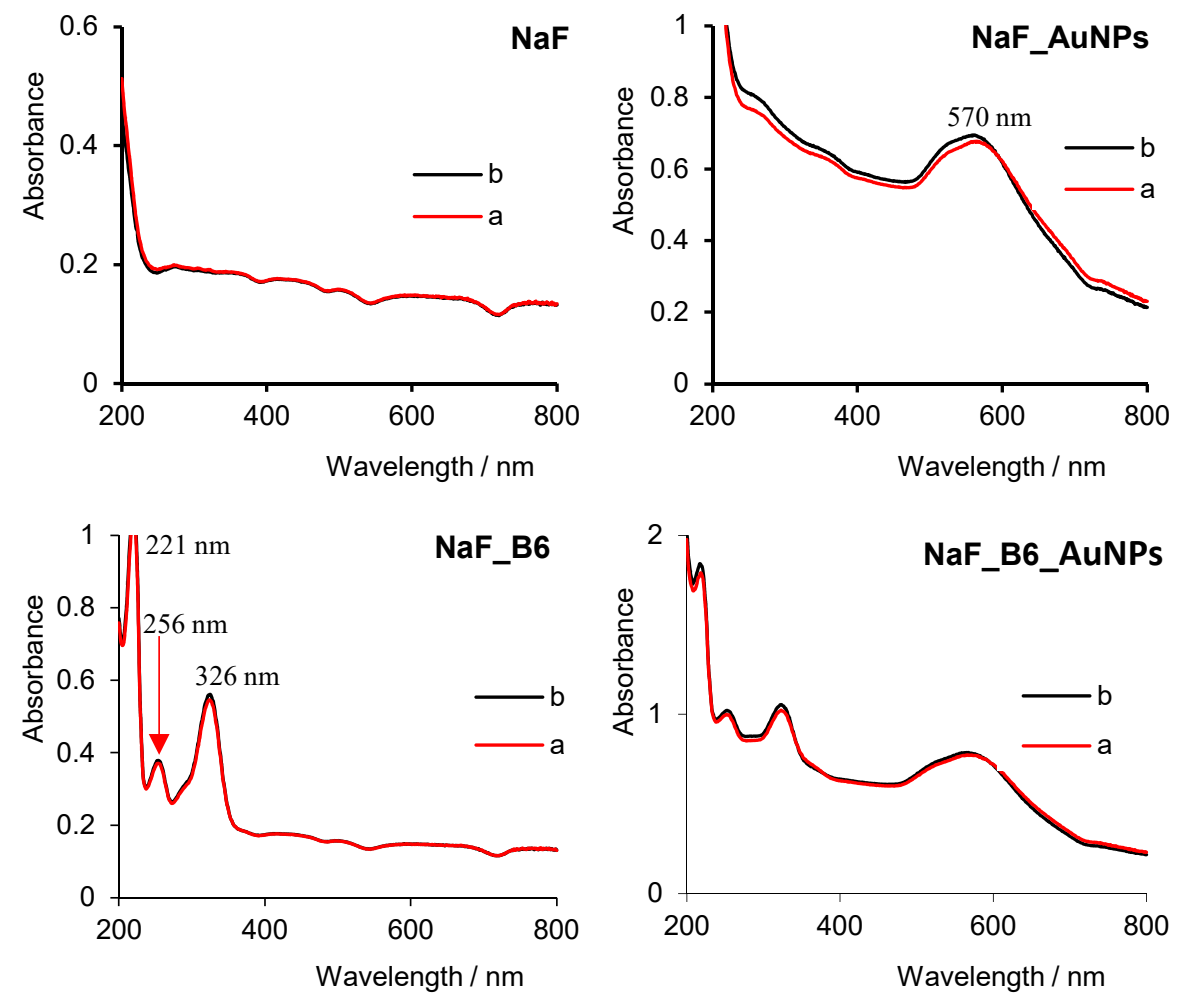

Figure 2. UV-Vis absorption spectra of electrolyte solution containing $\mathrm{NaF} / \mathrm{B}_{6} / \mathrm{AuNP}$ systems; $\mathrm{b}$-before and a-after performing cyclic voltammetry.

A comparison of the UV-Vis molecular absorption spectra of freshly prepared solutions, as well as after the recording of cyclic voltammograms, is presented in Figure 2.

The UV-Vis spectra corresponding to the support electrolyte solution (NaF) show a great similarity before (b) and after (a) the performance of cyclic voltammetry. This means that the supporting electrolyte influences the electrode processes only to a very small extent, for example through its high polarizability.

The UV-Visible spectrophotometer provides qualitative and quantitative information about the participation of AuNPs in electrode processes and implicitly about the modification of their properties. The presence of AuNPs in the electrolyte solution is confirmed by the absorption maximum recorded at the wavelength of $570 \mathrm{~nm}$ [37]. As can be seen in Figure 2 (NaF_AuNP spectra), during the recording of the cyclic voltammogram, the gold nanoparticles undergo both chemical and physicochemical changes. Thus, the spectrum recorded after the CV is located at slightly lower values of the absorbance, being the proof of their consumption in the electrode processes.

The spectral properties of the pyridoxine molecule are highlighted by three absorption maxima, in the UV range, corresponding to the wavelengths $\lambda \max =326,256$ and $221 \mathrm{~nm}$ [1]. Cyclic voltammetry is a "short-time" method, and therefore the processes of electrochemical degradation of pyridoxine cannot ensure a total consumption of pyridoxine molecules from the electrolyte solution. However, the UV-Vis spectrum of pyridoxine recorded after $\mathrm{CV}\left(\mathrm{NaF}_{-} \mathrm{B}_{6},-\mathrm{a}\right)$ is below the initial spectrum $\left(\mathrm{NaF}_{-} \mathrm{B}_{6},-\mathrm{b}\right)$, the electrocatalytic properties of the gold electrode being effective for the electrochemical degradation of this vitamin.

The UV-Vis spectrum of the electrolyte solution for the ternary system (NaF_B $\left.{ }_{6 \_} \mathrm{AuNPs}\right)$ corroborates the results obtained both by cyclic voltammetry and by spectrophotomet- 
ric analysis. Thus, this spectrum highlights both strong chemical interactions between ionic and molecular species present in the electrolyte solution and their electrochemical degradation.

The electrochemical behavior of pyridoxine over time has been studied in order to identify the electrochemical stability of the vitamin and how its stability is influenced by gold nanoparticles (Figure 3).
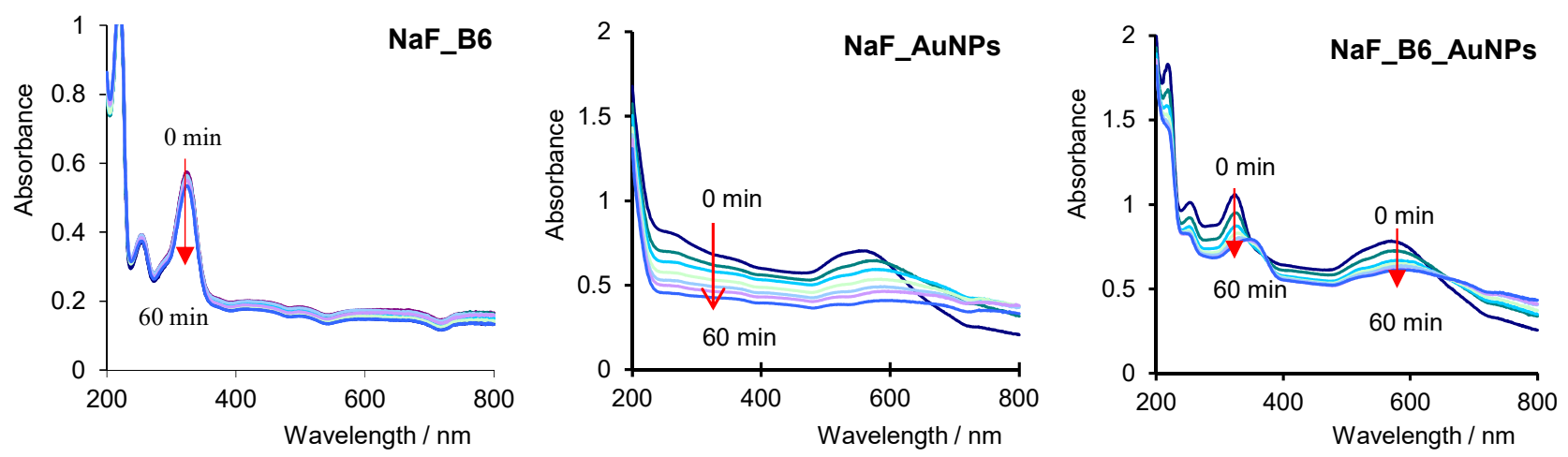

Figure 3. UV-Vis absorption spectra of work electrolyte solution as the electrochemical processes progress over time in $\mathrm{NaF} / \mathrm{B}_{6} /$ AuNP systems $\left(\mathrm{i}=50 \mathrm{~mA} \times \mathrm{cm}^{-2}\right)$.

Figure 3 shows the UV-Vis spectra during the electrode processes (current density $\left.=50 \mathrm{~mA} \times \mathrm{cm}^{-2}\right)$ for pyridoxine and gold nanoparticles, individually $\left(\mathrm{NaF}_{-} \mathrm{B}_{6}\right.$ and NaF_AuNPs) as well as together (NaF_B 6 _AuNPs).

The UV-Vis spectrum $\mathrm{NaF}_{-} \mathrm{B}_{6}$ indicates a gradual decrease in absorbance over time. In this electrolyte solution, vitamin molecules participate in redox processes, but there is only a minor decrease in absorbance corresponding to pyridoxine. An important indication is also given by the fact that no new absorption maxima are recorded. This indicates an electrochemical degradation of the pyridoxine to the final products that are not active in the analyzed spectrophotometric range $(200-800 \mathrm{~nm})$; pyridoxine molecules are most likely degraded to final products such as carbon dioxide, nitrogen oxides and water.

During electrolysis at a constant current density, the gold nanoparticles are also oxidized in the NaF support electrolyte solution. Under an electrical impulse, the UV-Vis spectra (NaF_AuNPs) recorded every $10 \mathrm{~min}$ show a total degradation at the end of the electrolysis of $60 \mathrm{~min}$.

The NaF_B ${ }_{6 \_} A u N P$ ternary system has two important features of evolution over time: (i) the absorbance values decrease over time, both those corresponding to pyridoxine and those corresponding to nanoparticles, and (ii) the absorption maxima show a slight shift towards longer wavelengths (bathochromic effect), both those corresponding to pyridoxine and those corresponding to nanoparticles.

The study of the processes that take place was continued by applying the kinetic models of the zero- and first-order reactions. The experimental data obtained by recording the variation of UV-Vis absorption spectra over time, of electrolyte solutions at constant current density, were used in the kinetic approach of the processes (Figure 4). Thus, the rate of electrochemical degradation processes of pyridoxine $(\lambda=326 \mathrm{~nm})$ and gold nanoparticles $(\lambda=570 \mathrm{~nm})$ was calculated (Table 1$)$. 

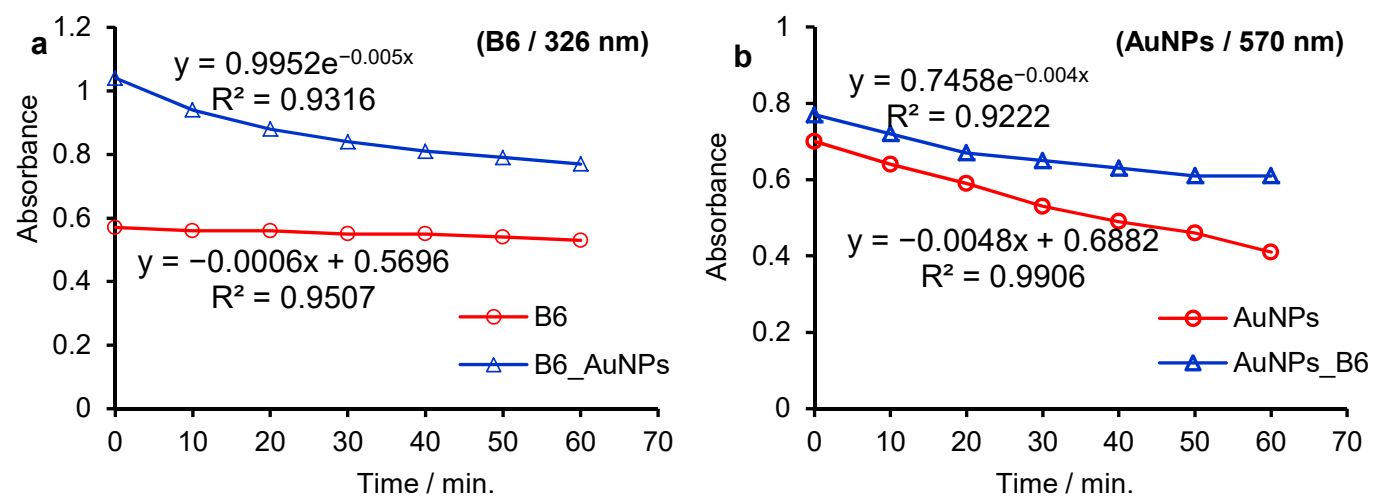

Figure 4. The kinetic models of the zero- and first-order reactions applied for $\mathrm{B}_{6}(\mathbf{a})$ and gold nanoparticles (b) electrochemical degradations.

Table 1. Kinetic parameters for $\mathrm{B}_{6}$ and AuNP electrochemical degradation, individual and mixed.

\begin{tabular}{ccc}
\hline Experimental Conditions & Kinetic Model & $\mathbf{k}$ \\
\hline $\mathrm{B}_{6}$ individual & zero-order reactions & $0.0006 \mathrm{u}$.Abs. $\times \mathrm{min}^{-1}$ \\
$\mathrm{~B}_{6}$ in the presence of AuNPs & first-order reactions & $0.005 \mathrm{~min}^{-1}$ \\
AuNPs individual & zero-order reactions & $0.0048 \mathrm{u}$.Abs. $\times \mathrm{min}^{-1}$ \\
AuNPs in the presence of $\mathrm{B}_{6}$ & first-order reactions & $0.004 \mathrm{~min}^{-1}$ \\
\hline
\end{tabular}

According to Figure 4a and Table 1, it is observed that the rate of electrochemical degradation of pyridoxine is higher in the presence of gold nanoparticles (there is a 7-fold increase). At the same time, a change in the initial absorbance value is highlighted, which proves a spontaneous chemical interaction between the pyridoxine molecules and the gold nanoparticles. Another important feature is that, in the presence of gold nanoparticles, it fits a first-order reaction model, which means that the rate is proportional to the concentration of a single reactant [57].

Gold nanoparticles exhibit opposite electrochemical behavior, both in the absence and in the presence of pyridoxine molecules. The difference between the value of the initial absorbance is very small $(0.73 \pm 0.04)$. In this situation, gold nanoparticles are characterized by high stability, their spectrum being modified to a very small extent. The presence of pyridoxine molecules in the electrolyte solution leads to a decrease in the rate of AuNP degradation.

In conclusion, it can be said that pyridoxine molecules delay the oxidation of AuNPs, while AuNPs accelerate the oxidation of pyridoxine molecules.

\subsection{The Influence of Chloride Ions on Electrochemical Behavior of Pyridoxine}

Chloride ions are part of the active electrolytes, so they participate in the electrode processes $[38,39]$. Under these conditions, the processes are different from the case of fluoride ions, ions that are electrochemically inactive.

Cyclic voltammetry responses of gold electrode in binary electrolyte solutions, $\mathrm{NaCl}_{-} \mathrm{B}_{6}$, $\mathrm{NaCl} \_\mathrm{AuNPs}$ and ternary $\mathrm{NaCl} \mathrm{B}_{6} \_\mathrm{AuNPs}$ are shown in comparison to those of the individual support electrolyte $(\mathrm{NaCl})$ in Figure 5. 

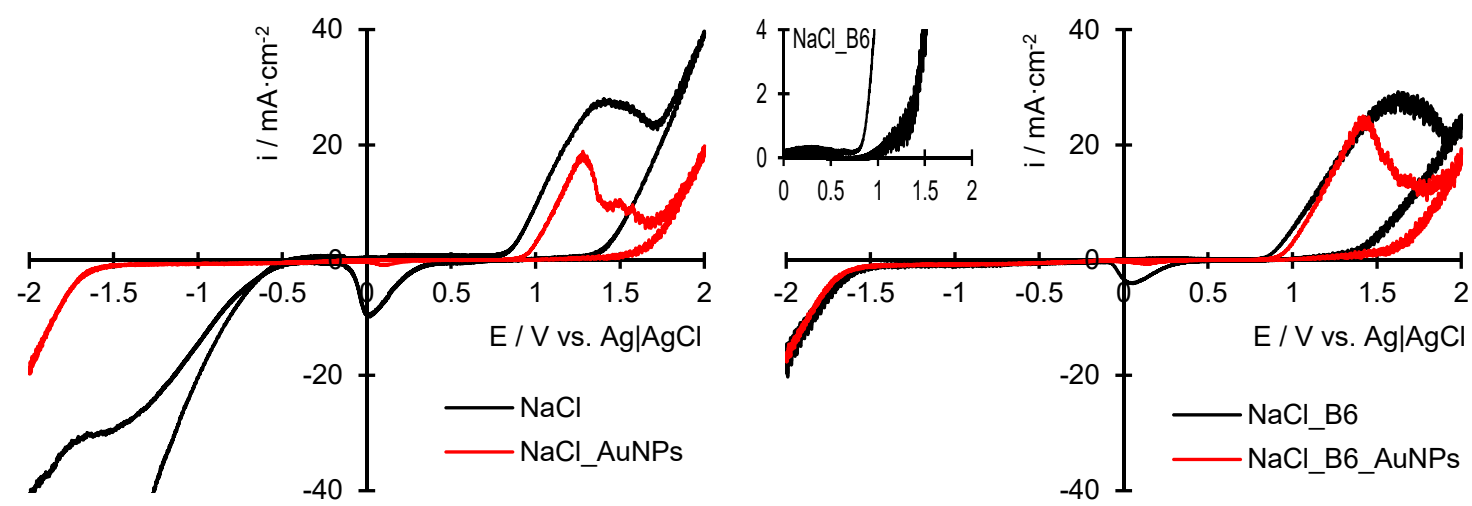

Figure 5. Cyclic voltammetry responses of gold electrode in $0.1 \mathrm{~mol} \times \mathrm{L}^{-1} \mathrm{NaCl}$ support electrolyte in the absence and in the presence of $75 \mathrm{mg} \times \mathrm{L}^{-1}$ gold nanoparticles (AuNPs) and $2.9 \times 10^{-4} \mathrm{~mol} \times \mathrm{L}^{-1}$ pyridoxine (vitamin $\mathrm{B}_{6}$ ).

The cyclic voltammograms in Figure 5 show an intensification of the electrode processes in the field of high anodic overvoltage. At a working electrode potential greater than $0.8 \mathrm{~V}$, the current densities increase significantly. The cyclic voltammogram indicates a wide, clearly contoured peak of the anodic current density, between 0.8 and $1.7 \mathrm{~V}$, specific to the oxidation of the gold electrode surface. This anodic peak retains its shape in the absence and presence of pyridoxine molecules but shows small changes in its characteristics. This anodic oxidation peak, although very wide, includes both the processes of the metal surface and the processes of organic molecules, clearly highlighted by the spectrophotometric analysis associated with cyclic voltammetry. The very high hysteresis of the cyclic voltammogram, recorded in the presence of chloride ions, indicates a very high susceptibility to oxidation and is due to the much higher aggressiveness of these ions. In this potential field, the oxidation of chloride ions also takes place, with the electrochemical generation of active chloride species, for example hypochlorite, chlorite, chlorate and perchlorate anions $[50,51,55]$. Anodic current densities increase 10 times more than in the case of fluoride ions, but in both cases, the current densities are reduced by the addition of gold nanoparticles.

The presence of AuNPs in the electrolyte solution leads to a decrease in both anodic and cathodic current densities. The presence of pyridoxine molecules in the electrolyte solution results in increased anodic current densities, associated with the electrooxidation of organic molecules on the surface of the gold electrode.

The cathodic peak recorded at the potential of $0.0 \mathrm{~V}$ is observed only in the absence of gold nanoparticles. This peak is of the irreversible type and, consequently, depends on the nature and composition of the electrolyte solution. Under these conditions, the structure and composition of the layer formed on the surface of the gold electrode may be different.

The results of the spectrophotometric analysis of the electrolyte solutions, before- $-\mathrm{b}$ and after-a, the recording of cyclic voltammograms are represented in Figure 6. 

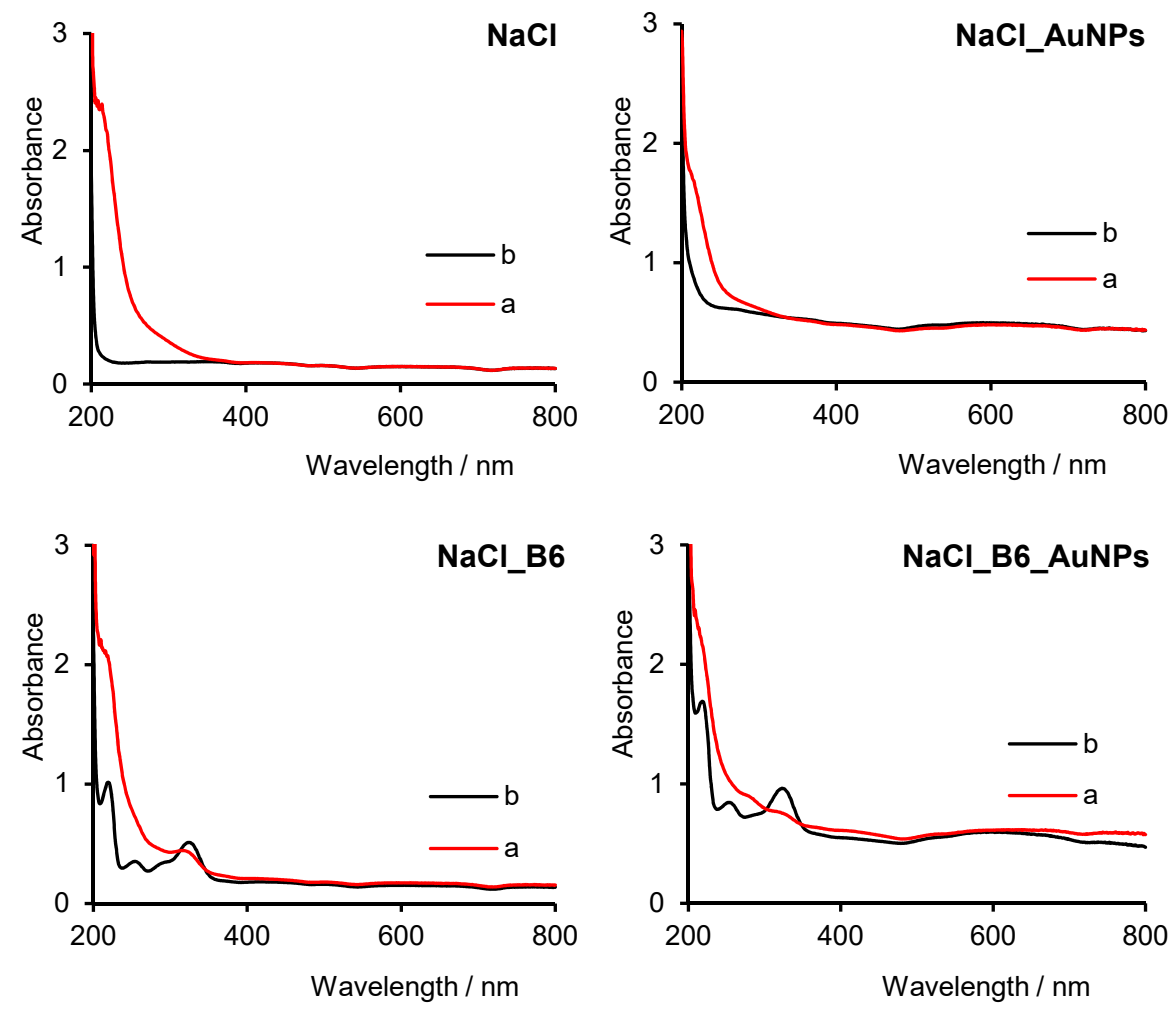

Figure 6. UV-Vis absorption spectra of electrolyte solution containing $\mathrm{NaCl} / \mathrm{B}_{6} / \mathrm{AuNP}$ systems; b-before and a-after performing cyclic voltammetry.

The UV-Vis spectrum of the support electrolyte solution, $0.1 \mathrm{~mol} \times \mathrm{L}^{-1} \mathrm{NaCl}$, shows an increase in absorbance at wavelengths less than $270 \mathrm{~nm}$ due to the presence of oxygenated chlorine compounds.

The presence of gold nanoparticles reduces absorbance; in other words, the nanoparticles prevent, to a greater or lesser extent, the electrooxidation of chloride ions. The absorption peaks corresponding to the vitamin are modified so that pyridoxine can no longer be identified qualitatively.

Spectral changes are identified for both the supporting electrolyte and the pyridoxine; however, the maximum absorption corresponding to gold nanoparticles does not undergo significant changes. This is a common feature of the electrochemical behavior of pyridoxine in the presence of chloride and fluoride ions.

The electrolyte solutions $\mathrm{NaCl} \_\mathrm{B}_{6}, \mathrm{NaCl} \_\mathrm{AuNPs}$ and $\mathrm{NaCl} \_\mathrm{B}_{6} \_\mathrm{AuNPs}$ were subjected to electrolysis at constant current density in association with UV-Vis spectrophotometric analysis. The UV-Vis spectra recorded every minute, over a period of $10 \mathrm{~min}$, are shown in Figure 7.
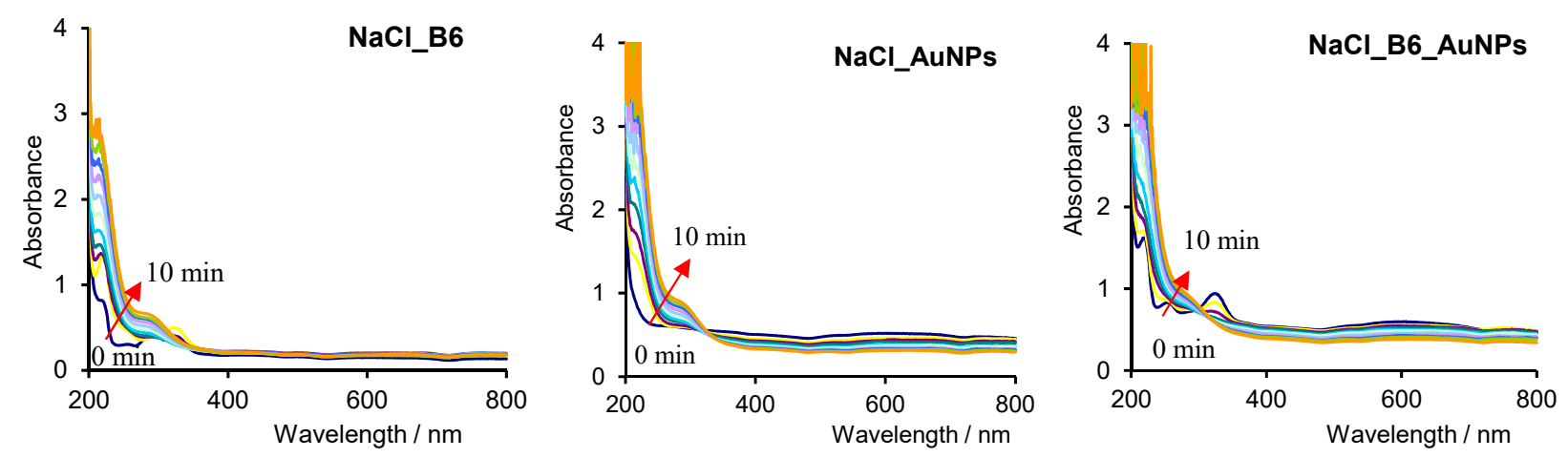

Figure 7. UV-Vis absorption spectra of sample as the electrochemical processes progress over time in $\mathrm{NaCl} / \mathrm{B}_{6} / \mathrm{AuNP}$ systems $\left(\mathrm{i}=50 \mathrm{~mA} \times \mathrm{cm}^{-2}\right)$. 
Figure 7 shows a strong solvatochromic effect in the $\mathrm{NaCl}_{-} \mathrm{B}_{6}$ system, compared to the $\mathrm{NaF}_{-} \mathrm{B}_{6}$ system, due to the interaction of chloride ions with the pyridoxine ring. It is observed that pyridoxine molecules are electrochemically degraded from the first minutes of electrolysis. In the presence of chloride ions, gold nanoparticles are also degraded from the first minutes of electrolysis. Thus, the processes take place at a much higher speed, and no effect of delay or catalytic activation of AuNPs can be observed.

The three spectra in Figure 7 are characterized by the appearance of a maximum absorption, of increasing intensity, at the wavelength of $293 \mathrm{~nm}$, attributed to the formation of chlorinated oxygen species [51].

\subsection{The Influence of Bromide Ions on Electrochemical Behavior of Pyridoxine}

Electrode processes are influenced by the nature and composition of the electrolyte solution. At high values of anodic overvoltage, the working electrode is active; thus, the composition and structure of the surface layer differ with the nature of the counterion.

Figure 8 shows the cyclic voltammograms of the gold electrode in the absence and presence of pyridoxine and gold nanoparticles in the supporting electrolyte represented by $0.1 \mathrm{~mol} \times \mathrm{L}^{-1} \mathrm{NaBr}$.
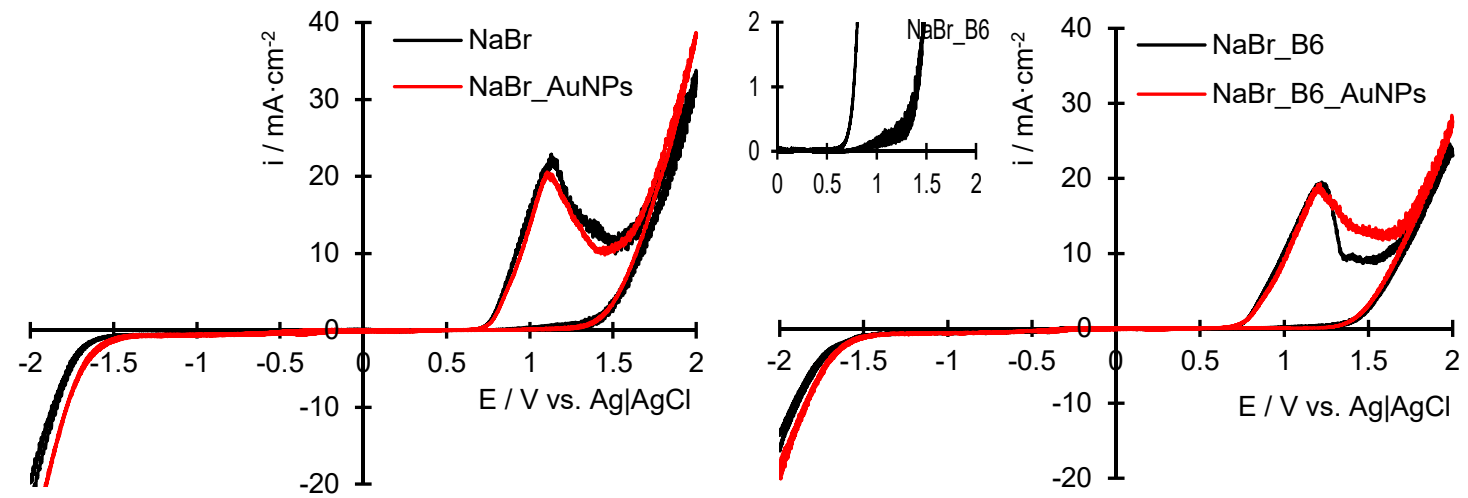

Figure 8. Cyclic voltammetry responses of gold electrode in $0.1 \mathrm{~mol} \times \mathrm{L}^{-1} \mathrm{NaBr}$ support electrolyte in the absence and in the presence of $75 \mathrm{mg} \times \mathrm{L}^{-1}$ gold nanoparticles (AuNPs) and $2.9 \times 10^{-4} \mathrm{~mol} \times \mathrm{L}^{-1}$ pyridoxine (vitamin $\mathrm{B}_{6}$ ).

A comparison of typical cyclic voltammograms, in the absence and presence of pyridoxine and AuNPs, for the gold electrode in aqueous $\mathrm{NaBr}$ solution is presented.

For all the considered electrolyte systems, the observed voltammetric response was in accordance with previous findings in the literature [58-60]. The systems are characterized by an anodic peak in the forward step and the absence of any peak on the reverse scan, indicating that the reaction is irreversible in all cases. As can be seen, pyridoxine provides smaller peaks at the same potential values relative to the Au electrode. However, the decrease is not very significant, from 21 to $16 \mathrm{~mA} \times \mathrm{cm}^{-2}$. This is due to the very good electrocatalytic properties of gold and implicitly to the phenomena of chemisorption of pyridoxine molecules on the surface of the gold electrode. The nature of the ion present in the working solution also has a major influence on the electrochemical mechanism. It can be seen that the bromide ion shifts the onset potential of pyridoxine oxidation to lower values compared to other anions, without being able to make a clear separation between the electrogeneration processes of oxybrominated species and the electrooxidation/electrotransformation processes of pyridoxine.

A peculiarity of the cyclic voltammograms recorded in the presence of bromide is the absence of the cathodic peak attributed to the reduction of oxygen species (gold oxides/hydroxides) on the metal surface.

To investigate the effect of bromide and AuNPs on the electrochemical stability of pyridoxine, a series of spectrophotometric experiments was performed in the corresponding binary and ternary electrolyte solutions (Figure 9). 

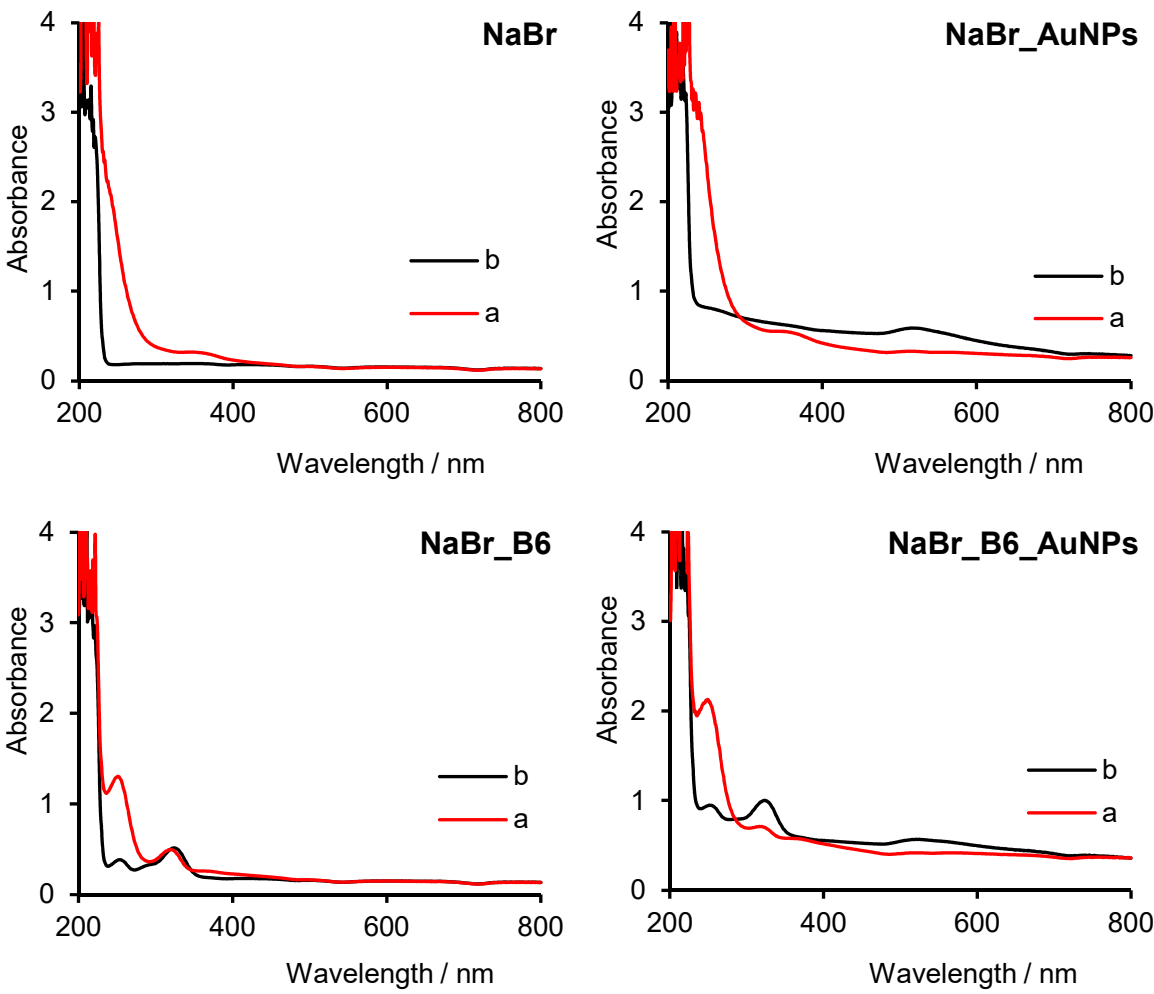

Figure 9. UV-Vis absorption spectra of electrolyte solution containing $\mathrm{NaBr} / \mathrm{B}_{6} / \mathrm{AuNP}$ systems; $\mathrm{b}$-before and a-after performing cyclic voltammetry.

The UV-Vis spectrum of the supporting electrolyte solution, obtained after $(\mathrm{NaBr}-\mathrm{a})$ recording the cyclic voltammogram, shows a slightly contoured peak at a wavelength of $331 \mathrm{~nm}$, attributed to the brominated electrogenerated species [51].

The presence of electrogenerated brominated species leads to the degradation of pyridoxine molecules both by direct mechanisms and by indirect and electromediated mechanisms. The spectra shown in Figure 9 demonstrate this, so that the spectrum recorded after performing the cyclic voltammetry shows a significant change in absorbance. The characteristic peak of AuNPs, at a wavelength of $570 \mathrm{~nm}$, disappears in both cases, both in the absence and in the presence of pyridoxine molecules.

To investigate the influence of AuNPs and halogen ions on the electrochemical behavior of pyridoxine, the spectrophotometric response of solutions subjected to electrolysis at constant current density was studied in the mixed electrolyte systems mentioned above (Figure 10).
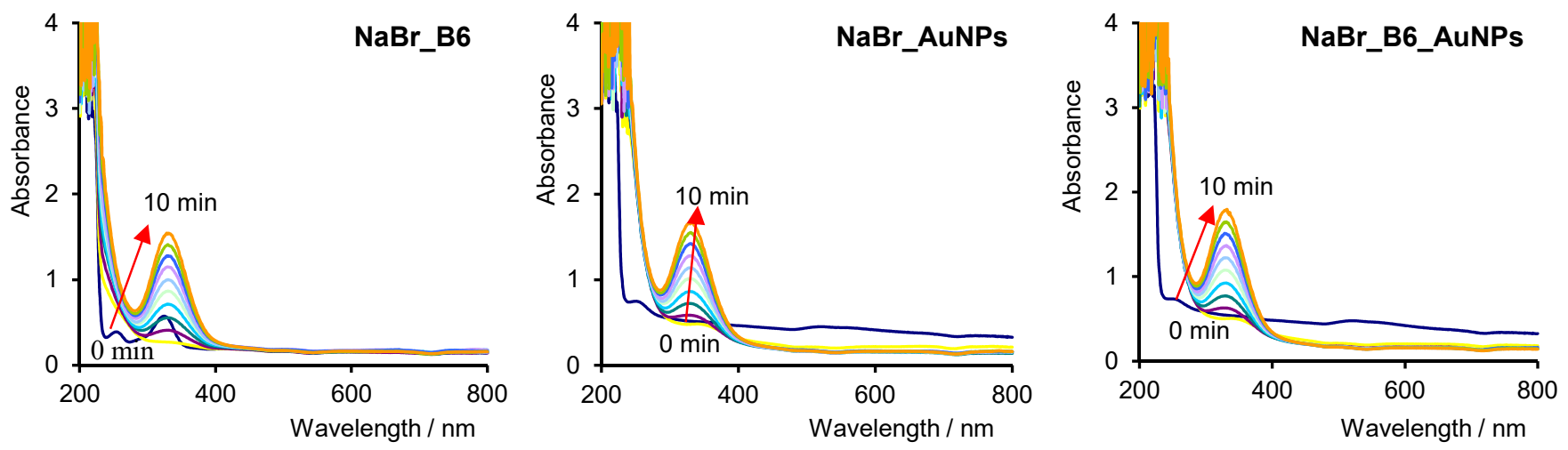

Figure 10. UV-Vis absorption spectra of sample as the electrochemical processes progress over time in $\mathrm{NaBr} / \mathrm{B}_{6} / \mathrm{AuNP}$ systems $\left(\mathrm{i}=50 \mathrm{~mA} \times \mathrm{cm}^{-2}\right)$. 
As expected, pyridoxine is practically oxidized on gold electrodes under the given experimental conditions, from the first minute of electrolysis, in either case $\left(\mathrm{NaBr}_{-} \mathrm{B}_{6}\right.$ and

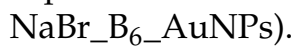

The predominant process is represented by the electrogeneration of brominated species, as can be seen in Figure 10; they indicate the appearance of an absorption peak at the wavelength of $331 \mathrm{~nm}$. Regarding the stability of AuNPs, the spectrophotometric analysis indicates the disappearance of the corresponding maximum absorption from the first moments of electrolysis without being influenced by the presence of pyridoxine molecules.

The interactions between molecular species and AuNPs in the presence of iodide ions can be of both practical and theoretical interest. According to previous studies [50], the $0.1 \mathrm{~mol} \times \mathrm{L}^{-1} \mathrm{NaI}$ solution has the lowest stability compared to that of the electrolytes containing the other sodium halides, namely $\mathrm{NaF}, \mathrm{NaCl}$ and $\mathrm{NaBr}$. As reported in our previous study [50], in the case of the $\mathrm{NaI}$ electrolyte containing drug, numerous interferences, before and after the electrochemical measurements, revealed in the wavelength range of 300-500 nm. These interferences would be multiplied in the presence of gold nanoparticles that absorb between 500 and $600 \mathrm{~nm}$, leading to illegible and uncommentable spectrophotograms.

\subsection{Mechanism of Electrochemical Degradation of Pyridoxine}

The detailed electrooxidation mechanism of pyridoxine on the gold electrode may involve complex multistep/multielectron reactions (Scheme 1).

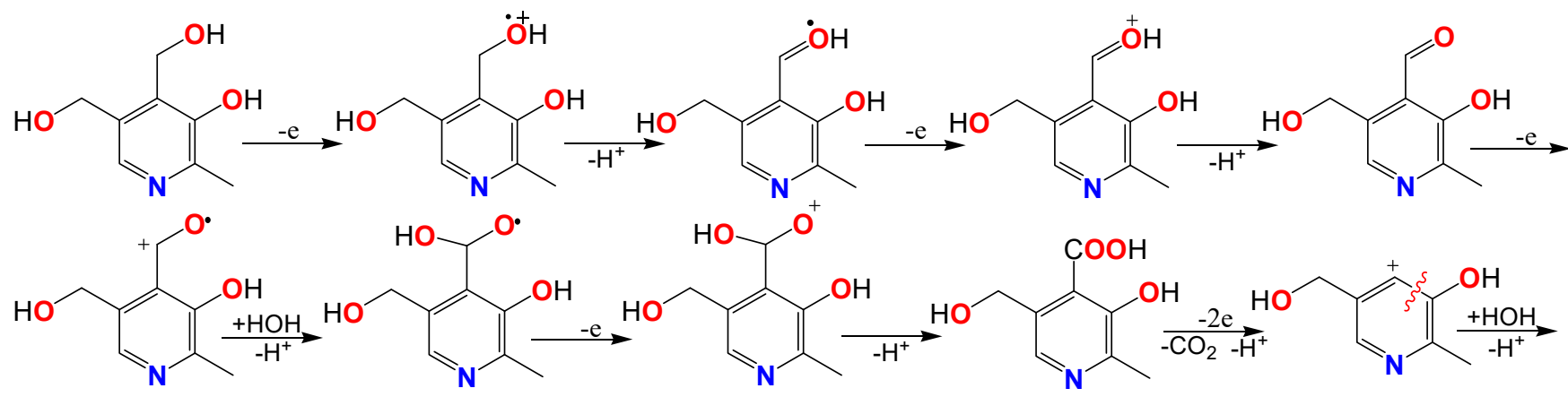

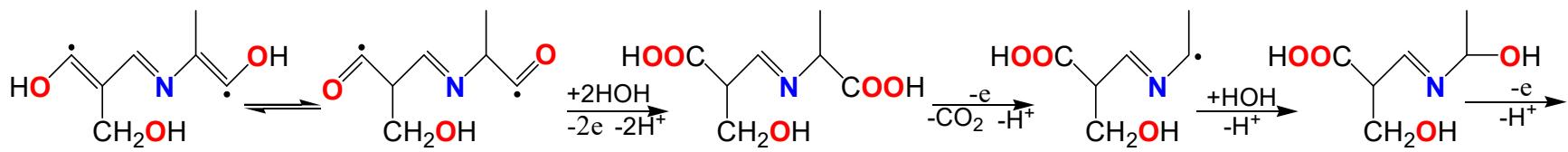

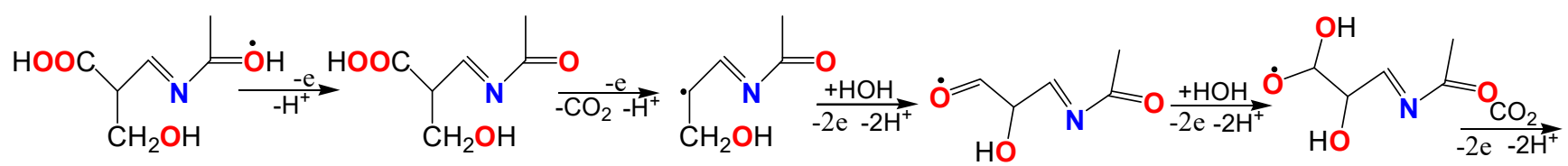

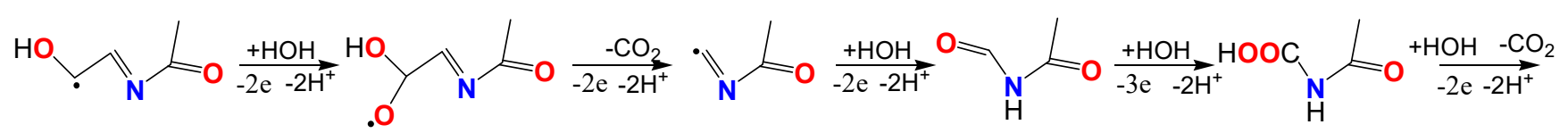

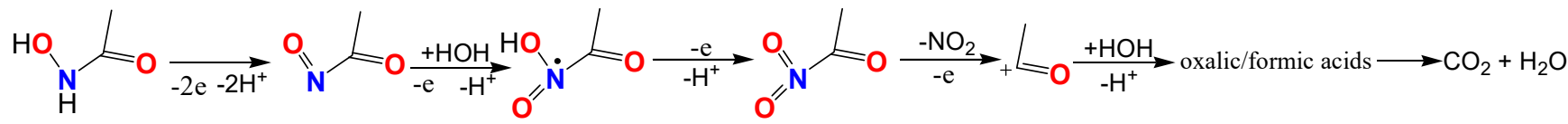

Scheme 1. The mechanism of electrochemical degradation of pyridoxine by a direct pathway.

Taking into account the electrocatalytic properties of the gold electrode, the pyridoxine molecules are adsorbed by chemisorption phenomena on the metal surface. In the pyridoxine molecule, position 4 has a high reactivity and, participating in successive electrochemical and chemical processes, oxidizes to pyridoxic acid [58,59]. This mechanism 
corresponds to a process of electrooxidation by a direct path. In other words, the transfer of electrons takes place directly on the surface of the working electrode.

This mechanism applies to experimental observations obtained in the presence of an inert support electrolyte, such as a fluoride ion. At the same time, the mechanism ensures the electrochemical degradation of pyridoxine to obtain inorganic final products such as nitrogen dioxide, carbon dioxide and water.

The pyridoxine molecule contains both heteroatoms with unbound electrons and $\pi$-electrons in the pyridine ring. Wang et al. showed that the interactions between the $\pi$-electrons of pyridoxine and the gold metal surface are insignificant [59]. The results of FT-IR vibrational spectroscopy showed that the pyridoxine molecule is fixed on the surface of the gold electrode by means of the nitrogen atom. These studies also highlight the intermediate formation in the electrooxidation of pyridoxic acid [59]. Subsequent decomposition of pyridoxic acid indicates intermediates containing $\mathrm{C}=\mathrm{O}$ and $\mathrm{C}-\mathrm{O}$ groups. Electrochemical oxidation of pyridoxine through the pyridoxal intermediate takes place on different electrodes, such as pyrolytic graphite electrodes, single-walled carbon nanotubes and multi-walled carbon nanotubes, glassy carbon electrodes, carbon ceramic electrodes and reduced graphene oxide $[35,58]$. Electrochemical oxidation occurs through unstable intermediates with a very short lifespan. Even the oxidation of pyridoxine to pyridoxal or pyridoxic acid results in indeterminacy that is not specified by in situ analysis [59].

Thus, the most stable intermediate species are pyridoxal and pyridoxic acid, which electrochemically decompose in final compounds, step-by-step passing through radicals, ionic or more complex species with short lifespan.

In the presence of active anions, such as chloride and bromide ions, the electrogeneration of oxidizing active species also involves a homogeneous process of electrochemical oxidation (indirect pathway).

In the presence of gold nanoparticles, the oxidation mechanism of pyridoxine may also involve the formation of gold ions, as well as the possibility of the formation of mixed gold compounds with pyridoxine or intermediate degradation compounds.

\section{Conclusions}

Halogen ions are assimilated in the human body from many food sources, and they play many metabolic roles. The administration of gold nanoparticles as a tonic and/or for antibacterial purposes can lead to unknown interactions with consequences that are difficult to understand. By the action of halide ions, gold nanoparticles can dissolve; chemical interactions between them can be spontaneous leading to the formation of potentially toxic chemical species.

This study demonstrates both the chemical and electrochemical interaction between pyridoxine molecules, halide ions and gold nanoparticles.

In the presence of inert support electrolytes, such as fluoride ions, gold nanoparticles catalyze the electrochemical degradation of pyridoxine molecules. At the same time, pyridoxine decreases the electrooxidative dissolution of gold nanoparticles.

Active electrolytes, chloride and bromide, lead to active electrogenerated species, so the electrochemical degradation of pyridoxine and nanoparticles takes place more easily. As a general conclusion, gold nanoparticles most easily degrade electrochemically in the presence of bromide ions and pyridoxine molecules in the presence of chloride ions.

Regarding the current trend in consuming foods and food supplements without rigorous information, it should be noted that there can be biological conditions conducive to adverse interactions having a negative impact. The novelty of this study is attributed to experimental results that introduce new evidence of spontaneous or practically induced interactions, which can occur in binary and ternary systems consisting of pyridoxine, AuNPs and halide ions.

This study should be continued with clinical trials to identify the benefits or, conversely, the adverse effects of the simultaneous administration of these compounds. 
Author Contributions: All authors had equal contribution to the article along with the first author. Conceptualization, A.S. and B.T.; methodology, A.S., C.-I.S. and B.T.; software, B.T. and B.O.; validation, B.O.; investigation, B.T.; resources, B.O. and C.T.; writing-original draft preparation, A.S. and B.T.; writing-review and editing, B.O.; supervision, A.S.; funding acquisition, B.T., C.-I.S., C.T. and B.O. All authors have read and agreed to the published version of the manuscript.

Funding: The funding of this work was supported by the research grants awarded by the University of Craiova, Romania, in the competition "The Awards of Research Results-ISI Articles".

Institutional Review Board Statement: Not applicable.

Informed Consent Statement: Not applicable.

Conflicts of Interest: The authors declare no conflict of interest.

\section{References}

1. Calori, I.R.; Gusmão, L.A.; Tedesco, A.C. $\mathrm{B}_{6}$ vitamers as generators and scavengers of reactive oxygen species. J. Photochem. Photobio. 2021, 7, 100041.

2. Wei, D.H.; Mao, Q.Q. Vitamin $\mathrm{B}_{6}$, vitamin $\mathrm{B}_{12}$ and methionine and risk of pancreatic cancer: A meta-analysis. Nutr. J. 2020, 19, 111. [CrossRef]

3. Merigliano, C.; Mascolo, E.; La Torre, M.; Saggio, I.; Verni, F. Protective role of vitamin B $_{6}$ (PLP) against DNA damage in Drosophila models of type 2 diabetes. Sci. Rep. 2018, 8, 11432. [CrossRef] [PubMed]

4. Baltrusch, S. The Role of neurotropic B vitamins in nerve regeneration. Biomed. Res. Int. 2021, 2021, 9968228. [CrossRef] [PubMed]

5. Hou, W.; Ji, H.; Wang, E. Liquid chromatography of vitamin $\mathrm{B}_{6}$ with electrochemical detection using a carbon fibre electrode. Anal. Chim. Acta 1990, 230, 207-211. [CrossRef]

6. Porter, K.; Lodge, J.K. Determination of selected water-soluble vitamins (thiamine, riboflavin, nicotinamide and pyridoxine) from a food matrix using hydrophilic interaction liquid chromatography coupled with mass spectroscopy. J. Chromatogr. B 2021, 1171, 122541. [CrossRef]

7. Marszałł, M.L.; Lebiedzinska, A.; Czarnowski, W.; Szefer, P. High-performance liquid chromatography method for the simultaneous determination of thiamine hydrochloride, pyridoxine hydrochloride and cyanocobalamin in pharmaceutical formulations using coulometric electrochemical and ultraviolet detection. J. Chromatogr. A 2005, 1094, 91-98. [CrossRef] [PubMed]

8. Marszałł, M.L.; Lebiedzinska, A.; Czarnowski, W.; Makarowski, R.; Kłos, M.; Szefer, P. Application of the high-performance liquid chromatography method with coulometric detection for determination of vitamin $\mathrm{B}_{6}$ in human plasma and serum. $J$. Chromatogr. B 2009, 877, 3151-3158. [CrossRef]

9. Hashem, H.; El-Sayed, H.M. Quality by design approach for development and validation of a RP-HPLC method for simultaneous determination of $\mathrm{co}-$ administered levetiracetam and pyridoxine $\mathrm{HCl}$ in prepared tablets. Microchem. J. 2018, 143, 55-63. [CrossRef]

10. Lebiedzinska, A.; Marszałł, M.L.; Kuta, J.; Szefer, P. Reversed-phase high-performance liquid chromatography method with coulometric electrochemical and ultraviolet detection for the quantification of vitamins $\mathrm{B}_{1}$ (thiamine), $\mathrm{B}_{6}$ (pyridoxamine, pyridoxal and pyridoxine) and $\mathrm{B}_{12}$ in animal and plant foods. J. Chromatogr. A 2007, 1173, 71-80. [CrossRef]

11. Portela, J.G.; Spínola Costa, A.C.; Teixeira, L.S.G. Determination of Vitamin $B_{6}$ in pharmaceutical formulations by flow injectionsolid phase spectrophotometry. J. Pharmaceut. Biomed. 2004, 34, 543-549. [CrossRef]

12. Hegazy, M.A.; Abdelwahab, N.S.; Fayed, A.S. A novel spectral resolution and simultaneous determination of multicomponent mixture of Vitamins $\mathrm{B}_{1}, \mathrm{~B}_{6}, \mathrm{~B}_{12}$, Benfotiamine and Diclofenac in tablets and capsules by derivative and MCR-ALS. Spectrochim. Acta A 2015, 140, 524-533. [CrossRef] [PubMed]

13. Dena, A.S.A.; Ammar, A.A. H-point standard addition for simultaneous reagent-free spectrophotometric determination of $B_{1}$ and $\mathrm{B}_{6}$ vitamins. Spectrochim. Acta A 2019, 206, 491-497. [CrossRef] [PubMed]

14. Tsuge, $\mathrm{H}$. Determination of vitamin $\mathrm{B}_{6}$ vitamers and metabolites in a bioloical sample. Method. Enzymol. 1997, $280,3-12$.

15. Sun, J.F.; Ren, C.L.; Liu, L.H.; Chen, X.G. CdTe quantum dots as fluorescence sensor for the determination of vitamin $B_{6}$ in aqueous solution. Chin. Chem. Lett. 2008, 19, 855-859. [CrossRef]

16. Jastrzebska, A.; Kowalska, S.; Szłyk, E. New procedure for column-switching isotachophoretic determination of vitamins $B_{1}$ and $\mathrm{B}_{6}$ in beer samples. J. Food Compos. Anal. 2017, 57, 80-86. [CrossRef]

17. Huang, L.; Tian, S.; Zhao, W.; Liu, K.; Guo, J. Electrochemical vitamin sensors: A critical review. Talanta 2021, $222,121645$. [CrossRef]

18. Barthus, R.C.; Mazo, L.H.; Poppi, R.J. Simultaneous determination of vitamins C, $B_{6}$ and PP in pharmaceutics using differential pulse voltammetry with a glassy carbon electrode and multivariate calibration tools. J. Pharmaceut. Biomed. 2005, 38, 94-99. [CrossRef]

19. Wang, H.; Zhang, X.; Wang, S.; Xiao, S.; Ma, H.; Wang, X. Multianalyte electrochemical electrode for the determination of vitamins $\mathrm{B}_{2}$ and $\mathrm{B}_{6}$ in complex biosystem. Microchem. J. 2020, 158, 105233. [CrossRef] 
20. Nie, T.; Xu, J.-K.; Lu, L.-M.; Zhang, K.-X.; Bai, L.; Wen, Y.-P. Electroactive species-doped poly(3,4-ethylenedioxythiophene) films: Enhanced sensitivity for electrochemical simultaneous determination of vitamins $\mathrm{B}_{2}, \mathrm{~B}_{6}$ and C. Biosens. Bioelectron. 2013, 50, 244-250. [CrossRef]

21. Prasad, P.S.; Kumar, S.P.; Bharathi, K.; Narayanan, V. Determination of Vitamin $-B_{6}$ by Vanadium (III) Schiff base complex modified GCE. Mater. Today Proc. 2018, 5, 9026-9032. [CrossRef]

22. Razmi, H.; Mohammad-Rezaei, R. Flow injection amperometric determination of pyridoxine at a Prussian blue nanoparticle-modified carbon ceramic electrode. Electrochim. Acta 2010, 55, 1814-1819. [CrossRef]

23. Fonseca, C.A.; Vaz, G.C.S.; Azevedo, J.P.A.; Semaan, F.S. Exploiting ion-pair formation for the enhancement of electroanalytical determination of pyridoxine $\left(\mathrm{B}_{6}\right)$ onto polyurethane-graphite electrodes. Microchem. J. 2011, 99, 186-192. [CrossRef]

24. Mesgari, F.; Beigi, S.M.; Salehnia, F.; Hosseini, M.; Ganjali, M.R. Enhanced electrochemiluminescence of $\mathrm{Ru}(\mathrm{bpy})_{3}{ }^{2+}$ by $\mathrm{Sm}_{2} \mathrm{O}_{3}$ nanoparticles decorated graphitic carbon nitride nano-sheets for pyridoxine analysis. Inorg. Chem. Commun. 2019, 106, $240-247$. [CrossRef]

25. Westmacott, K.L.; Crew, A.; Doran, O.; Hart, J.P. A novel electroanalytical approach to the measurement of B vitamins in food supplements based on screen-printed carbon sensors. Talanta 2018, 181, 13-18. [CrossRef]

26. Sonkar, P.K.; Ganesan, V.; Gupta, S.K.S.; Yadav, D.K.; Gupta, R.; Yadav, M. Highly dispersed multiwalled carbon nanotubes coupled manganese salen nanostructure for simultaneous electrochemical sensing of vitamin $\mathrm{B}_{2}$ and $\mathrm{B}_{6}$. J. Electroanal. Chem. 2017, 807, 235-243. [CrossRef]

27. Barsan, M.M.; Toledo, C.T.; Brett, C.M.A. New electrode architectures based on poly(methylene green) and functionalized carbon nanotubes: Characterization and application to detection of acetaminophen and pyridoxine. J. Electroanal. Chem. 2015, 736, 8-15. [CrossRef]

28. Raj, M.A.; Gowthaman, N.S.K.; John, S.A. Highly sensitive interference-free electrochemical determination of pyridoxine at graphene modified electrode: Importance in Parkinson and Asthma treatments. J. Colloid Interf. Sci. 2016, 474, 171-178. [CrossRef] [PubMed]

29. Li, Y.; Li, H.; Li, M.; Li, C.; Sun, D.; Yang, B. Porous boron-doped diamond electrode for detection of dopamine and pyridoxine in human serum. Electrochim. Acta 2017, 258, 744-753. [CrossRef]

30. Kuzmanović, D.; Khan, M.; Mehmeti, E.; Nazir, R.; Amaizah, N.R.R.; Stanković, D.M. Determination of pyridoxine (vitamin B 6 ) in pharmaceuticals and urine samples using unmodified boron-doped diamond electrode. Diam. Relat. Mater. 2016, 64, 184-189. [CrossRef]

31. Manoj, D.; Rajendran, S.; Qin, J.; Sundaravadivel, E.; Yola, M.L.; Atar, N.; Gracia, F.; Boukherroub, R.; Gracia-Pinilla, M.A.; Kumar Gupta, V. Heterostructures of mesoporous $\mathrm{TiO}_{2}$ and $\mathrm{SnO}_{2}$ nanocatalyst for improved electrochemical oxidation ability of vitamin B6 in pharmaceutical tablets. J. Colloid Interf. Sci. 2019, 542, 45-53. [CrossRef]

32. Ranjith Kumar, D.; Manoj, D.; Santhanalakshmi, J.; Shima, J.-J. Au-CuO core-shell nanoparticles design and development for the selective determination of Vitamin $\mathrm{B}_{6}$. Electrochim. Acta 2015, 176, 514-522. [CrossRef]

33. Vaze, V.D.; Srivastava, A.K. Determination of pyridoxine hydrochloride in pharmaceutical preparations by calixarene based potentiometric sensor. J. Pharmaceut. Biomed. 2008, 47, 177-182. [CrossRef] [PubMed]

34. Pires, A.R.; Araujo, A.N.; Conceicao, M.; Montenegro, B.S.M.; Chocholous, P.; Solich, P. New ionophores for vitamin B 1 and vitamin $\mathrm{B}_{6}$ potentiometric sensors for multivitaminic control. J. Pharmaceut. Biomed. 2008, 46, 683-691. [CrossRef]

35. Santhy, A.; Saraswathyamma, B.; Krishnan, A.P.; Luscious, L. Nanomaterials incorporated electrochemical sensors for the monitoring of pyridoxine: A mini review. Mater. Today Proc. 2021, 46, 2998-3004. [CrossRef]

36. De Souza, C.D.; Nogueira, B.R.; Rostelato, M.E.C.M. Review of the methodologies used in the synthesis gold nanoparticles by chemical reduction. J. Alloy. Compd. 2019, 798, 714-740. [CrossRef]

37. Ramalingam, V. Multifunctionality of gold nanoparticles: Plausible and convincing properties. Adv. Colloid Interfac. 2019, 271, 101989. [CrossRef] [PubMed]

38. Tutunaru, B.; Samide, A.; Neamtu, C.; Tigae, C. Spectroelectrochemical studies of interactions between vitamin A and nanocolloidal silver. Int. J. Electrochem. Sci. 2018, 13, 5850-5859. [CrossRef]

39. Samide, A.; Tutunaru, B. Interactions between vitamin C and nanocolloidal silver particles studied by cyclic voltammetry and UV-Vis spectrophotometry. Electroanalysis 2017, 29, 2498-2506. [CrossRef]

40. Medici, S.; Peana, M.; Coradduzza, D.; Zoroddu, M.A. Gold nanoparticles and cancer: Detection, diagnosis and therapy. Semin. Cancer Biol. 2021, in press. [CrossRef]

41. Liu, X.-Y.; Wang, J.-Q.; Ashby, C.R., Jr.; Zeng, L.; Fan, Y.-F.; Chen, Z.-S. Gold nanoparticles: Synthesis, physiochemical properties and therapeutic applications in cancer. Drug Discov. Today 2021, 26, 1284-1292. [CrossRef] [PubMed]

42. Sani, A.; Cao, C.; Cui, D. Toxicity of gold nanoparticles (AuNPs): A review. Biochem. Biophys. Rep. 2021, 26, 100991. [PubMed]

43. Jaswal, T.; Gupta, J. A review on the toxicity of silver nanoparticles on human health. Mater. Today Proc. 2021, in press. [CrossRef]

44. Akter, M.; Sikder, M.T.; Rahman, M.M.; Ullah, A.K.M.A.; Hossain, K.F.B.; Banik, S.; Hosokawa, T.; Saito, T.; Kurasaki, M.A. Systematic review on silver nanoparticles-induced cytotoxicity: Physicochemical properties and perspectives. J. Adv. Res. 2018, 9, 1-16. [CrossRef]

45. Dabhane, H.; Chatur, S.; Jadhav, G.; Tambade, P.; Medhane, V. Phytogenic synthesis of gold nanoparticles and applications for removal of methylene blue dye: A review. Environ. Chem. Ecotoxicol. 2021, 3, 160-171. [CrossRef] 
46. Fathima, R.; Mujeeb, A. Nonlinear optical investigations of laser generated gold, silver and gold-silver alloy nanoparticles and optical limiting applications. J. Alloy. Compd. 2021, 858, 157667. [CrossRef]

47. Kazancioglu, E.O.; Aydin, M.; Arsu, N. Photochemical synthesis of bimetallic gold/silver nanoparticles in polymer matrix with tunable absorption properties: Superior photocatalytic activity for degradation of methylene blue. Mater. Chem. Phys. 2021, 269, 124734. [CrossRef]

48. Heinemann, M.G.; Rosa, C.H.; Rosa, G.R.; Dias, D. Biogenic synthesis of gold and silver nanoparticles used in environmental applications: A review. Trends Environ. Anal. 2021, 30, e00129. [CrossRef]

49. Al-khattaf, F.S. Gold and silver nanoparticles: Green synthesis, microbes, mechanism, factors, plant disease management and environmental risks. Saudi J. Biol. Sci. 2021, 28, 3624-3631. [CrossRef]

50. Tutunaru, B.; Samide, A.; Iordache, S.; Tigae, C.; Simionescu, A.; Popescu, A. Ceftriaxone degradation in the presence of sodium halides investigated by electrochemical methods assisted by UV-Vis spectrophotometry. Appl. Sci. Basel 2021, 11, 1376. [CrossRef]

51. Iordache, S.; Tutunaru, B.; Samide, A.; Tigae, C.; Simionescu, A.; Popescu, A. Electrochemical degradation and thermal deactivation of valproic acid drug. Int. J. Electrochem. Sci. 2021, 16, 210346. [CrossRef]

52. Tutunaru, B.; Samide, A.; Moanta, A.; Ionescu, C.; Tigae, C. Electrochemical study of metribuzin pesticide degradation on bismuth electrode in aqueous solution. Int. J. Electrochem. Sci. 2015, 10, 223-234.

53. Samide, A.; Tutunaru, B.; Tigae, C.; Efrem, R.; Moanta, A.; Dragoi, M. Removal of Methylene Blue and Methyl Blue from wastewater by electrochemical degradation. Environ. Prot. Eng. 2014, 40, 93-104. [CrossRef]

54. Samide, A.; Dumitru, M.; Ciuciu, A.; Tutunaru, B.; Preda, M. Electrochemical treatment of acid wastewaters containing Methylorange. Studia Univ. Babes-Bolyai Chem. 2009, 54, 157-169.

55. Tutunaru, B.; Tigae, C.; Spînu, C.; Prunaru, I. Spectrophotometry and electrochemistry of Brilliant Blue FCF in aqueous solution of NaX. Int. J. Electrochem. Sci. 2017, 12, 396-412. [CrossRef]

56. Gonzalez-Rodriguez, J.; Sevilla, J.M.; Pineda, T.; Blazquez, M.; López-Guerrero, M.M. A study on the electrooxidation of vitamin $\mathrm{B}_{6}$ compounds on glassy carbon and polycrystalline gold electrodes. J. Electroanal. Chem. 2020, 877, 114525. [CrossRef]

57. Samide, A.; Tutunaru, B.; Varut, R.-M.; Oprea, B.; Iordache, S. Interactions of some chemotherapeutic agents as epirubicin, gemcitabine and paclitaxel in multicomponent systems based on orange essential oil. Pharmaceuticals 2021, 14, 619. [CrossRef]

58. Brunetti, B.; Desimoni, E. Voltammetric determination of vitamin $\mathrm{B}_{6}$ in food samples and dietary supplements. J. Food Compos. Anal. 2014, 33, 155-160. [CrossRef]

59. Wang, M.L.; Zhang, Y.Y.; Xie, Q.J.; Yao, S.Z. In situ FT-IR spectroelectrochemical study of electrooxidation of pyridoxol on a gold electrode. Electrochim. Acta 2005, 51, 1059-1068. [CrossRef]

60. Lee, J.H.Q.; Lauw, S.J.L.; Webster, R.D. The electrochemical reduction of carbon dioxide $\left(\mathrm{CO}_{2}\right)$ to methanol in the presence of pyridoxine (vitamin $\mathrm{B}_{6}$ ). Electrochem. Commun. 2016, 64, 69-73. [CrossRef] 